\title{
Bone metabolism, bone mass and structural integrity profile in professional male football players.
}

Journal: The Journal of Sports Medicine and Physical Fitness

Paper code: J Sports Med Phys Fitness-9913

Submission date: April 13, 2019

Article type: Original Article

Files:

1. Reply letter to comments on the manuscript

Version: 3

Description: Rebuttal letter

File format: application/vnd.openxmlformats-officedocument.wordprocessingml.document

2. Manuscript

Version: 5

Description: Manoscritto originale

File format: application/vnd.openxmlformats-officedocument.wordprocessingml.document

3. Figures 1

Version: 1

Description: Figure 1

File format: image/jpeg 
We thank the reviewers for their positive comments. We improved the manuscript according to the they suggestions. All the changes are underline with the yellow colour in the manuscript.

\section{Commento 1}

General comment (originality, scientific accuracy, strengths and/or weaknesses): Originality: the aim is not new; good scientific accuracy. Strengths: attention to supplementation of athletes. Weaknesses: CUS in the evaluation of bone quality, and in the same tirne is useless in saccer players for at least two reasons: first they are very young ( $<24$ yrs old $)$ and second is rell known that soccer is a protective factors for bone quality. Major corrections (main criticisms): No major criticism Minor corrections (page, paragraph, line where the author must make the Corrections): Minor: please discuss the role of soccer in preventing bone quality and geonetric properties.

ANSWER: Thanks to the reviewer for this positive comment. Ansyggest we added the role of soccer in preventing bone quality and geometric properties page 3, lines 14-20).

\section{Commento 2}

General comment coriginality, scientific aecuracy, strengths and/or weaknesses): Overall this is a straightforward and well carried gut pilot study of bone biochemical measures (i.e., serum parathyroid hormone, urinary caleium, serum Vitamin D etc.) in relation to joint, musculoskeletal injuriesin 16 young adult Prale professional football players from October -May. Samples were obtained at the begining (Oct) and end (May) of the season.

Major corrections (main criticisms): the researchers indicate the participants had less than 10 hours/week of sunlight. This is not verified nor are the methods to determine sunlight exposure given (i.e., self-report, direct observation). Please provide these details in the manuscript methodology section.

ANSWER: The sunlight exposure has been evaluated by using a self-report questionnaire (Hanwell HE, et al. J Steroid Biochem Mol Biol 2010;121:334-7). See new reference \#37, page 5, line 8. 
One accepted measure of sunlight exposure is standard erythema doses (SEDs) and takes into account intensity and duration of exposure. Please provide the SEDs for the participants. ANSWER: We agree with the referee that the standard erythema dose (SED)is a good and accepted methods for the sunlight exposure, however it has not been considered in ihis study.

I also found it difficult to have confidence that the soccer players had less than 1 hour of exposure of sunlight per day from October-May. How was this determined and verified? Fuller methodological description is necessary here.

ANSWER: Valle d'Aosta is a mountain region sited in the Italian Alps. Weather is cold, rainy and snowy, especially in autumn and winter. The football players trainedindogrs and the estimated sun exposure for outdoors training is less than $10 \mathrm{hrs}$ a wee. We added this information also in the text (page 5, lines 10-12).

The sample size is small $(\mathrm{n}=16)$ and non-parametrie statistics appe aprote (i.e., Mann-Whitney U test).A short statement about why non-parametric tests were used(i.e, small sample, distribution free) would be useful for the reader as would a rationale for selecting the Mann-Whitney U test (as opposed to another independent sample ordinaltest such ass the Kolmogorov-Smirnov two sample test).

ANSWER: we better explain the rationate for setecting the Mann-Whitney $U$ test (page 7, lines 11-13).

Table 1. the standard deviations are quite large for a number of the biochemical parameters: serum alkaline phosphatase, serum parathyroid hormone, urinary calcium and urinary phosphorus. The researchers need to explain why there was so much variability in these measures. There is no indication of when (time) these measures were taken, which could contribute to the variability and lack of significant findings.

ANSWER: venous blood samples were obtained From $08: 00$ to $08: 30$ am after 12 hours fast. We added this information in the revised manuscript (page 6, line 8-10).

Given the small sample size, the researchers should provide a power calculation to ensure the sample size was indeed large enough to see significant effects. 
ANSWER: The sample size was not provided because it is a pilot study performed on a small series of subjects who were all member of the soccer team of Valle d'Aosta.

Minor corrections (page, paragraph, line where the author must make the corrections): There are some minor spelling and grammatical mistakes throughout the manuscript. page 1, line 41. "Wit this pilot study...." should be "With this pilot study" ANSWER: We correct as suggested (page 2, line 19).

page7, line 45 "confirming that vitamin D contributes with the correct function of musculoskeletal system." should be "...contributes to the correction function of....

ANSWER: We correct as suggested, also according to the next comment (page 9, lines 12). page 7, lines 41-45. This statement is too strong. A correlation is not causation. Please tone down. ANSWER: We reformulate this sentence as follow: "indicating that vitamin D might contribute to the correction function of musculoskeletal system" (page 9, tives 12).

\section{Commento 3}

General comment (originality, scientific accuracy, strengths and/or weaknesses): The study has some interesting prospects and provides information which may be helpful to coaches and performance trainers.

Major corcections (man criticisms): There are no real major criticisms.

ANSWER: We are grateful to the reviewer \#3 for his positive comment.

Minor corrections (page, paragraph, line where the author must make the corrections): Page Line Comment

241 "Wit" should be with".

ANSWER: We correct as suggested (page 2, line 19).

3 14-15 There doesn't seem to be much transition from the injury paragraph to the BMD paragraph. Plus, the 2nd paragraph doesn't seem to flow well.

ANSWER: We decided to not separate the part of injury and BMD in two paragraphs, so we were 
able to better connect these two (page 3, lines 7-8), and we described better the part of BMD (page 3, lines 14-20), adding also new references (\#5, 11-17).

333 Same problem; there doesn't seem to be a logic to transition to this paragraph. In addition, what is the relevance of list illnesses related to Vit D deficiency that is not relevant to your topic of BMD?

ANSWER: we reformulated the introduction of this paragraph related to vitamin $D$ (page 3 , lines 21-23).

351 How does Vit D prevent falls [“decline in falls"]?

ANSWER: we changed "decline" with "prevent". The role of vitamin D ingreventing falls is explained at page 4, lines 1-4. We underlined that adding a sentence (page 4, line 3).

42 This reference is in adolescent girls. Are there any studies reitive to mâse athletes in various sports?

ANSWER: we added Koundourakis NE al, PLOS One 2014 frevence \#30, page 4, line 4).

417 "However, in the Italian population...."

ANSWER: we changed it as suggested (page 4, linent).

426 Once more, the transition to the purpose does not seem to be there. Since there is only one study in Italian footbail players, how does that promote your study?

ANSWER: as suggested. Wee better explain the conclusion and the bias of this Italian study (page 4, lines 13-17). In this way, the differences between our study and this previous study are better underlined.

552 How long had they been fasting before the blood sample.

ANSWER: a 12-hrs fasting has been observed before blood sample. We added this information in the revised manuscript. (page 6, line 9).

632 How was the bone quality index (BQI) calculated?

ANSWER: BQI is calculated directly by the device software and is calculated from the 
quantitative ultrasound index (QUI). We rewrote the part on "Calcaneal quantitative ultrasound measurement and radiographic calcaneal examination" and better explained how BQI, as well as the other ultrasound parameters, were calculated (page 6, line 21-24 and page 7, lines 1-8).

641 Should "Ligue" be "League". It appears that these to re used interchangeably throughout. It would be better to use League since that is the English version.

ANSWER: as suggested, we changed "ligue" with "League" in the entire manuscript.

645 It might be better to rearrange this sentence rather than start it with a lower-case letter, $p$. ANSWER: we rearranged it as "Values of p..." (page 7, lines 14-15).

76 Should "pf" be "of"?

ANSWER: we corrected it (page 7, line 20)

728 "There was a correlation ...." Should also give the correfation andexpress its significance level?

7 32-35 Again, should also give the correlations and express their significance level?

739 What does it mean to say that the correlations did nof yspersist" until the end of League play? How much did they drop-off; was it a significant decdine?

ANSWER: we reformulated the last part of the results according to reviewer comments (page 8, lines 6-16). In the revised version of the manuscript, we added the " $r$ " of Pearson correlation (if significant) and the R and $p$ vatue from the linear regression. Moreover, we also added the fold change between the begiwing and the end of the League for the more significant parameters (see also page 7, line 23 and page 8, lines 1-2). Except for vitamin D levels, we did not observe significant differences of the different parameters between the beginning and the end of the League. However, phosphaturia, which is the parameters that changed more at the end of the League, was also the parameter with more significant correlation. We supposed that, this changing in phosphaturia, even if is not significant, could be the reason why we did not observe the correlations found at the beginning of the League also at its end. We added this comment also in the discussion (page 10, lines 6-11). 
1

752 Should there be a comma after "women's football"?

ANSWER: we corrected it (page 8, line 20)

813 Again, the transition to this paragraph from the one talking about accidents, mistakes, and injuries seems $\mathrm{t}$ be lacking to immediately change tact to talking about Vit D,

ANSWER: we improved this part underlying the association between the injuries and vitamin $D$ (page 9, lines 1-2).

815 "it" should be "it's".

ANSWER: we changed the entire sentence (page 9, lines 1-2).

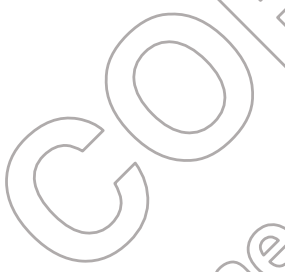

841 "foud" should be "found"

ANSWER: we corrected it (page 9, line 14).

845 Should be "with" be "to"?

ANSWER: we changed the entire sentence (page 9, line tó).

849 "showed" should be "shown".

ANSWER: we corrected it (page 9, line 18).

96 Eliminate the "rotween "which" and Temains".

ANSWER: we corrected it (page9, line 22).

919 "Moreover, QtSS allows...."

ANSWER: we corrected it (page 10, line 4).

919 "...the bone strength independent of BMD"

ANSWER: we corrected it (page 10, line 4).

9 24-28 Where the correlations mentioned here positive or negative?

ANSWER: we better explained the observed correlations (page 10, lines 6-11). 
Page 7 of 40

1

2

3

4

5

6

7

8

934 Eliminate "belonging"

ANSWER: we deleted it in two point of the manuscript (page 4, line 19 and page 10, line 14).

102 "....and for improving athletic performance."

ANSWER: we corrected it (page 10, line 23).

1412 Should height and weight be included in this table?

ANSWER: we added this information in Table 1.
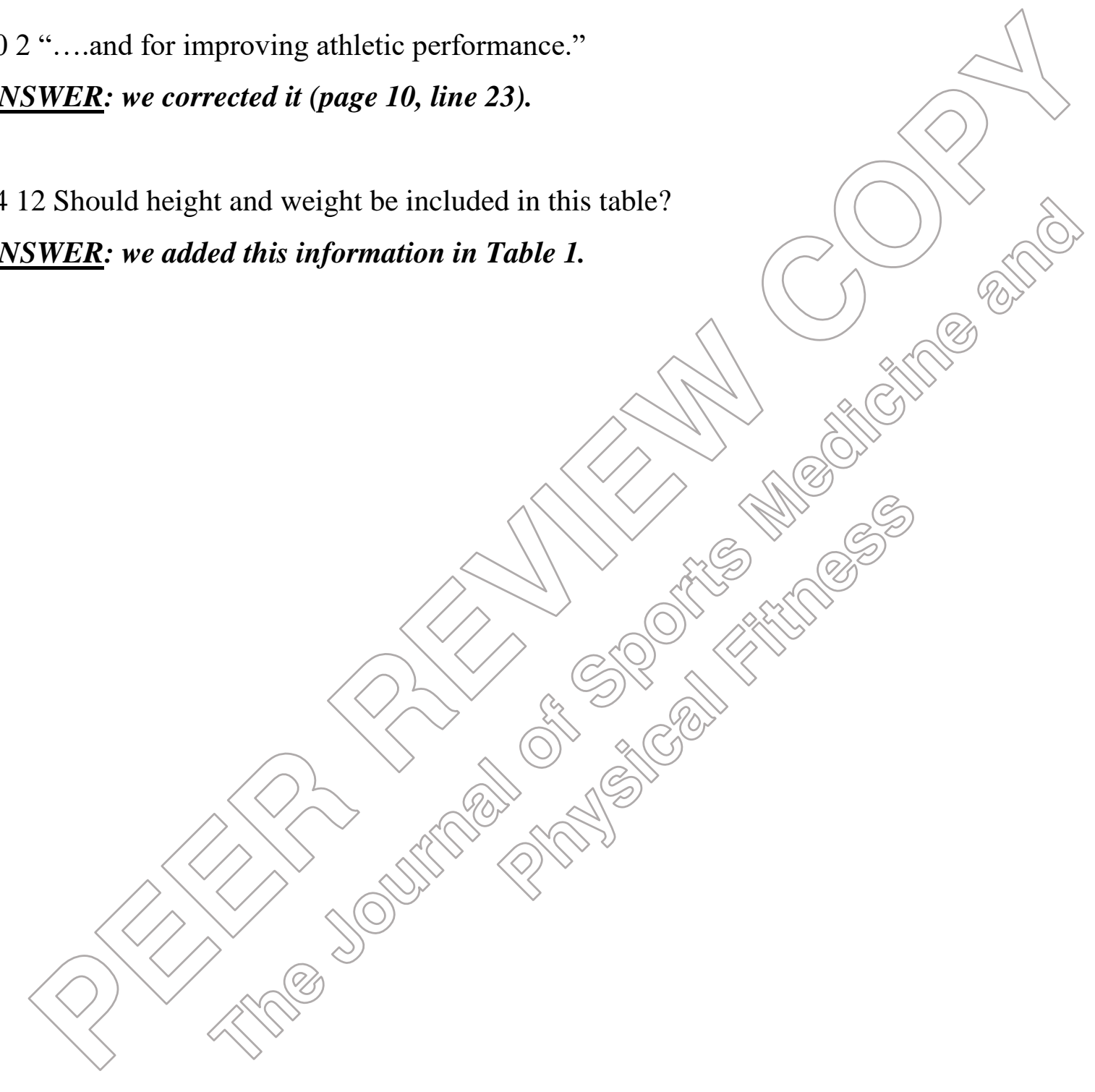
Bone metabolism, bone mass and structural integrity profile in professional male football players.

Mariagiovanna Filippella ${ }^{1,2}$, Barbara Altieri ${ }^{3}$, Alberto Falchetti ${ }^{4}$, Roberta Cosso ${ }^{4}$, Hellas Cena ${ }^{5}$, Corrado Musso $^{6}$, Erica Geronutti ${ }^{1}$, Luciano Rassat $^{1}$, Giulia Cipriani ${ }^{7}$, Annamaria Colao $^{3}$, Carolina Di Somma $^{3}$, Antongiulio Faggiano ${ }^{8}$.

${ }^{1}$ Medicine and Rehabilitation Clinical Institute of Aosta, Italy.

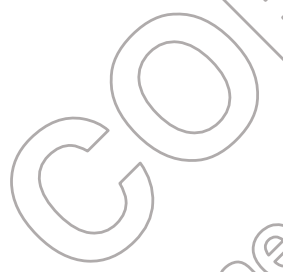

${ }^{2}$ Nutrition and Metabolism Unit, Humanitas Gavezzani, Bergamo, Italy.

${ }^{3}$ Department of Clinical Medicine and Surgery, Federice IN University of vaples, Naples, Italy.

${ }^{4}$ EndOsMet Division, Branch of Metabolic Bone Diseases, MiPas Donatello Private Hospital, Florence, and Service of Endocrinology and Bone Metabolism Disease Herciani Centre of Bologna, Italy.

${ }^{5}$ Department of Public Health, Experimental Medicine and forensic, Unit of Food Sciences University of Pavia, Italy.

${ }^{6}$ Unit of Neurosurgery Humanitas of Bergam arrd Pelycininc of Monza, Italy.

${ }^{7}$ Sangro Health Systein, L) Aquila, Italy.

${ }^{8}$ Department of Experimental Medicine, Sapienza University of Rome, Rome, Italy.

Short Title: Bone metabolism and hypovitaminosis D in football players.

Conflict of interest: the authors declare that they have no conflicts of interest.

\section{Corresponding Author:}

Altieri Barbara, $\mathrm{MD}, \mathrm{PhD}$

Department of Clinical Medicine and Surgery,

Federico II University of Naples,

Via Sergio Pansini 5, 82121,

Naples, Italy. 


\begin{abstract}
BACKGROUND: Physical exercise plays an important role in bone mineralization as well as factors involved in bone metabolism influence the athletic performance. In European countries, soccer is the most popular sport. The aim of the study was to investigate bone metabolism, bone mass and structural integrity profile in professional male adult football players.
\end{abstract}

METHODS: Sixteen professional male football players from a single team of the 2nd division Italian League (mean age 22.4 \pm 0.7 years) were enrolled. Bone biochemical parameters, ineruding serum calcium, phosphorus, albumin, creatinine, alkaline phosphatase, intact plasmagTH, 25-hydroxyvitamin D (25-OHD), 24-h urinary calcium and phosphorus, and calcaneaf quantitative ultrasound (QUS), were evaluated at the beginning (October 2012), and at the eng of the League (May 2013).

RESULTS: 25-OHD levels were significantly lower at the end of the Peague compared to the beginning $(27.1 \pm 5.9$ vs $36.6 \pm 9.5 \mathrm{ng} / \mathrm{ml}$, fold change $(\mathrm{FC})=0.25, P=0.008)$, and the prevalence of 25-OHD deficiency increased from 25 to $73 \%$. Mreaver, higher rate of previous bone, cartilage or ligament injuries correlated with 25-OHD deficiencies ( $(B)=0.014)$. T-score and Z-score were at the upper limits of the normality ranges, without significant difference between the beginning and end of the League. Phosphaturia was slightiy decreased at the end of the League [(691.0 \pm 364.5 vs $934.0 \pm$ $274.3 \mathrm{mg} / 241 \mathrm{~F} \mathrm{~F}=0.26, p=0.06)]$. A significant correlation was found between phosphaturia and $\mathrm{BQI}(\mathrm{R}$ square $=0.28, p=0.03)$, and both $\mathrm{T}-\mathrm{s}$ and $\mathrm{Z}-\mathrm{s}(\mathrm{R}$ square $=0.28, p=0.03)$ at the beginning of the League.

CONCLUSIONS: With this pilot study, we demonstrated that vitamin D status significantly worsened at the end of the League. Therefore, vitamin D supplementation might be suggested in adult football players in order to prevent vitamin D deficiency and improve the athletic performance.

Key Words: Bone turnover; Bone Mineral Density; vitamin D; football players. 


\section{Introduction}

Soccer is the worldwide most popular sport, with about 200 million players, both professionals and amateurs ${ }^{1}$. Several risk factors for soccer injuries have been described ${ }^{2}$, including 1) the level of play, the risk appears to be higher in professional than amateur players; 2) the exercise load; and 3) the standard of training ${ }^{3}$. The main types of injury are traumatic, such as fracture, contusion or hematoma, laceration, muscle or tendon strain and joint or ligament sprains and/or overuse, injuries ${ }^{4}$. To the other side, sports with high impact or odd-impact loading, including soccer, are associated with higher bone mineral composition and bone mineral density (BMD) ${ }^{5}$. Many studies reported that the increased BMD in athletes was mainly due to the strain resulting fromimpact bone loading, rather than, and independently from, muscle strength increase 6 . However. most st difies have been conducted in girls and only occasionally in men 7,8 . Exercise seems t tohave benefer al effects on bone tissue by stimulating the osteogenic responses 9,10 . Soccer is onaractefized by various types of running with rapid changes of direction, starts, stops, jumping, and kicking resulting in large ground reaction forces at the skeleton, and thus can be classified as angrmpact loading sport ${ }^{6}$. Several studies have demonstrated that soccer have a positive effects on bone mass and those effects are greatest during growth $5,11,12$. However, this effect on bone health could be explained not only to an improvement of BMD, but also to an improvement of bone geometry, evaluated by with peripheral quantitative computed tomography or hip structural analysis ${ }^{13,14}$. Different studies demonstrated that young adult soccer players had better bone geometry, including cortical area, periosteal circumference and volumetric bone mineral density, than matched controls in both genders ${ }^{15-17}$.

A crucial role in bone health and mineralization is played by Vitamin D, due its role in the regulation of calcium and phosphorus metabolism ${ }^{18}$. Vitamin D deficiency is a worldwide health problem ${ }^{19-23}$ and it is associated with impaired neuromuscular function, bone loss and fractures ${ }^{24-26}$. More specifically, it has been shown that vitamin D levels correlate with grip and quadriceps strength, 
physical fitness, and prevent falls and bone fractures ${ }^{27}$. Particularly, vitamin D deficiency predominantly affects the weight-bearing antigravity muscles of the lower limbs, which are necessary for walking and postural balance ${ }^{27,28}$, explained its role in preventing falls. Furthermore, vitamin D supplementation seems to boost muscular strength and restores balance ${ }^{28-30}$. Previous studies, on different small sized football players' populations from different European Countries, have been published regarding possible relationship between seasonal variation of serum vitamin D levels and bone turnover markers (BTMs), body mass, body composition, total body water, tat-1ree mass, muscle mass, exercise performance such as squat jump, coantermovement jump 10 and 20 meters sprint performance, maximal oxygen consumption (VQ2max), anthropometry, lower limb isokinetic function, race, fracture history, and the ability to obtain a contract dossition ${ }^{30-35}$. However, in the Italian population, only a single study on twenty-three football playersevaluated the possible correlation between seasonal vitamin D levels and dual x-ray absorptiometry (DXA)-measured bone mineral content (BMC) ${ }^{36}$. The authors found that both vitanin D levels and BMC significantly decreased from autumn to winter, indicating that supplementation of vitamin D might be necessary during the winter period 36 However, the athors did not evaluate other parameters involved in bone metabolism, including phosphorus, albumin, creatinine, alkaline phosphatase, parathyroid hormone (PTH), as weil as they did notevaluate the bone structural integrity profile.

The aim of our study was to investigate the correlation between bone metabolism markers with bone mass and structural integrity profile in a professional male adult football players from a single team. Therefore, we evaluated also whether the rate of previous bone, cartilage or ligament injuries could be correlate with vitamin $\mathrm{D}$ deficiencies. 


\section{Patients and Methods}

\section{Patients}

Sixteen professional male football players of the S.C. Vallée d'Aoste, a 2nd division Italian club (mean age 22.4 \pm 0.7 years, range 19-28 years), were enrolled and evaluated at the beginning (October 2012) and at the end of the league (May 2013). The study protocol was approved by the local ethics committee institutional board and was carried out in accordance with the ethical standards laid down in the 1964 Declaration of Helsinki as revised in 2000. Informed consent was obtained from all the subjects included in this study. All subjects were placed on astandardized diet witis greater than 1000 mg elemental calcium per day starting 2 months before the beginning of the study. None of the participants had been taking vitamin D supplements or arugs known tom interfere with bone or mineral metabolism for the last 12 months. The sun exposure, evaluated by usine a self-report questionnaire ${ }^{37}$, was less than 10 hours/week for a11 participants. This could be explained by the fact that Valle d'Aosta is a mountain region sited in the Italian ips where weather is generally cold, rainy and snowy, especially in autumn and winter, and that football players trained mostly indoors. Exclusion criteria were acute or chronic conditions that affest nîneral metabolism or complete immobilization.

\section{Clinical characteristics assessment}

Height, weight, body rass index (BMI), systolic blood pressure (SBP) and diastolic blood pressure (DBP) were evaluated by standard methods. Exercise duration was also assessed. BMI was measured as the ratio between the weight and the square of the height. A BMI between 25 and $30 \mathrm{Kg} / \mathrm{m}^{2}$ indicated a condition of over-weight, whereas BMI greater than $30 \mathrm{Kg} / \mathrm{m}^{2}$ indicated a condition of obesity ${ }^{38}$. Waist circumference (WC) was measured to the nearest $0.1 \mathrm{~cm}$ at the end of a normal expiration by measuring from the narrowest point between the lower borders of the rib cage and the iliac crest. The measurement were performed with the patients in standing position with relaxed 
abdomen, arms at sides, and joined feet ${ }^{39}$. Blood pressure was measured in the right arm, with the subjects in a relaxed sitting position. The average of 6 measurements ( 3 taken by each of 2 examiners) with a mercury sphygmomanometer was used. Arterial blood hypertension was diagnosed when DBP values were $\geq 85 \mathrm{mmHg}$ and SBP values were $\geq 130 \mathrm{mmHg}$ in line with Adult Treatment Panel III 40.

\section{Biochemical assessment}

From 08:00 to 08:30 am, venous blood samples were obtained following a ten-minute period of rest in a lying position, after 12 hours-fasting, in order to determine the concentration of all biochemical parameters. Serum concentrations of creatinine, cailcium, phosphorus, albumin, total alkaline phosphatase (ALP) were determined at fasting by automated techniqueg KRoche Modular System). Serum concentrations of intact parathyoid hormones(ipTH) were measured by electrochemiluminescence immunoassay concent Stion. Serum concentrations of 25-hydroxyvitamin D (25-OHD) were measured with direct radiojinmunoassay. According to the Endocrine Society guidelines ${ }^{41}$, a condition of vitamin $D$ insufficiency was defined by a serum concentration of 25 OHD between 20-30 $\mathrm{ng} / \mathrm{ml}$, while a condition of vitamin $\mathrm{D}$ deficiency was defined by serum concentrations of $25-\mathrm{OHD}$ below $20 \mathrm{ng} / \mathrm{ml}$. 24-h urine samples were analyzed for urinary calcium and phosphorus measurements. Creatinine clearance was also determined.

\section{Calcaneal quantitative ultrasound measurement and radiographic calcaneal examination}

Quantitative ultrasound (QUS) of the calcaneus was performed using the Sahara clinical bone sonometer (Hologic INC, USA). The calcaneus of participants was placed between two ultrasound transducers that are positioned on opposite sides to each other. This device provides measures of the velocity and frequency attenuation of the sound wave propagation through bone by the "speed of 
sound" (SOS; $\mathrm{m} / \mathrm{s}$ ) and the "broadband ultrasound attenuation" (BUA; $\mathrm{dB} / \mathrm{MHz}$ ) of an ultrasound beam passed through the calcaneus between the two transducers, and the "quantitative ultrasound index" (QUI), which is a combination between SOS and BUA. These two parameters reflect different bone properties, including density, elasticity and microarchitecture ${ }^{42}$. Bone mineral density (BMD), T-score (T-s) and Z-score (Z-s) were derived from the manufacturer reference database and provided by the software device. The QUI is converted directly by Sahara software in "bone quality index" (BQI), an assessment of calcaneus BMD $\left(\mathrm{g} / \mathrm{cm}^{2}\right)$. BQI is easy to interpret and indicates bone composition and structure. Its normal range is between 0 to 150 .

\section{Statistical Analysis}

Numerical data are expressed as mean \pm standard deviation (SD). Due the small sample size and the non-normally-distributed data, differences between the experimental periods in the measured parameters were analyzed by the non-parametric Mann-Whitney U test. A logistic regression analysis and a linear correlation analysis by calculating the Pearsores coefficient were performed. Values of $p<0.05$ were considered statistically sigrificant. Statistical analysis was performed with SPSS statistical software package (version, 20.0, SPs S; Chicago, IL).

\section{Results}

Clinical, biochemical and BMD parameters both at the beginning and at the end of the League were summarized in Table 1. At the beginning of the League all evaluated parameter were within the normal range (Table 1).

Phosphaturia was slightly but not significantly decreased at the end compared to the beginning of the League $[(691.0 \pm 364.5$ vs $934.0 \pm 274.3 \mathrm{mg} / 24 \mathrm{~h}$, fold change $(\mathrm{FC})=0.26, p=0.06)]$, while serum calcium, phosphorus and iPTH as well as calciuria were unchanged (Table 1). 25-OHD serum levels 
were significantly reduced at the end of the League in comparison to the beginning $(27.1 \pm 5.9 v \mathrm{~s}$ $36.6 \pm 9.5 \mathrm{ng} / \mathrm{ml}, \mathrm{FC}=0.25, p=0.008)$. In parallel, the prevalence of 25-OHD deficiency increased from 25 to $73 \%$ at the end of the League. The rate of previous bone, cartilage or ligament injuries correlated with the 25-OHD deficiencies $(p=0.014)$ (Figure 1). Particularly, subjects with lower vitamin D levels had a history of higher number of injuries.

No significant differences between the beginning and the end of the League were observed for BQI $(138.5 \pm 17.7$ vs $133.7 \pm 15.3, \mathrm{FC}=0.03, p=0.45), \mathrm{T}$-s and $\mathrm{Z}$-s (in both cases, $1.7 \pm 1.1 \times 51.6 \pm 1.0$, $\mathrm{FC}=0.05, p=0.48$ ), which were at the upper limits of normal range. BQI significantly correlate with both T-s and Z-s $(\mathrm{r}=1, \mathrm{R}$ square $=0.99, p<0.001)$ at the two tme-points of the study. Interestingly, a significant positive correlation was found between phosphaturia and bone parameters, including BQI (R square $=0.28, p=0.03$ ), and both T-s and $\mathrm{Z}-\mathrm{s}$ ( $\mathrm{R}$ square $=0.28, p=0.03$, for Both) at the beginning of the League. Moreover, phosphaturia also signiticantly correlated with the duration of soccer activity ( $\mathrm{R}$ square $=0.68, p=0.0005$ ). A trend of positive correlation was also demonstrated between both T-s and Z-s and the duration of soccer activity ( $R$ square $=0.23, p=0.09)$ and calciuria $(\mathrm{R}$ square $=0.24$, $p=0.052$ ). However, these trends were observed only at the beginning of the League, whereas were not found after its end.

\section{Discussion and conciusiens}

The greater frequency of football accidents in recent years across all sectors, both professional and amateur ${ }^{43,44}$, youth football ${ }^{45}$ and women's football ${ }^{46}$, has been the subject of several studies and publications. Many accidents are unforeseeable as they are the natural consequences of sport in which speed, strength and explosive action are accompanied by physical contact, tackling and collisions with an opponent. Many others, however, could be avoided because they stem from mistakes, underestimation of the risk factors, or insufficient consideration of the ways in which they can be 
prevented. One risk factor could be represented by vitamin D deficiency, which impairs bone loss, neuromuscular function and postural balance, increasing the risk of fractures ${ }^{24-28}$. Morton et al. ${ }^{47}$ demonstrated a significant reduction in serum levels of 25-OHD in a group of professional soccer players of the English Premier League at the latitude of $53^{\circ} \mathrm{N}$ between the summer and the winter period (in August and December). Similarly, a study in Spanish professionalsocer players who trained at the latitude of $37^{\circ} \mathrm{N}$ showed a statistically significant reduction im serum levels of 25-OHD between these two time periods (October and February) ${ }^{31}$. Moreover, several studies have shown a considerable correlation of vitamin D levels with muscle stracture and strength $31,48,49$. Visser et al. ${ }^{50}$ found that a $25-\mathrm{OHD}$ level of $30 \mathrm{ng} / \mathrm{ml}$ guarantees optimal muscle function. Close et al ${ }^{51}$ suggest that decreased vitamin D levels are one of the important causes of reduced exercise capabilities in athletes.

In accordance with previous studies 31,47, we observed that 25-OHBoserum levels were significantly reduced at the end of the League as compared to trie beginning, as well as the prevalence of 25-OHD deficiency according to the Endocrine Society guidelines increased from 25 to $73 \%$. We also found that the rate of previous bone, cartilage of digament injuries correlated with the 25-OHD deficiencies, indicating that vitainin D might contribute to the correction function of musculoskeletal system.

Conflicting results on the impact of physical activity on serum of PTH are reported in the literature. Particularly, it has been shown that in athletes pursuing performance disciplines, serum levels of PTH were lower than in physically inactive subjects ${ }^{52}$. In our study we did not observed any differences in PTH levels during the beginning and the end of the League. Only phosphaturia was slightly but not significantly decreased at these two time points.

Bone mass status was evaluated using the QUS method. Different from the DXA, which remains the gold standard technique for measuring the BMD, QUS is an attractive alternative method of bone assessment because it is a non-invasive technique, radiation-free, low-cost, simple, and is portable. 
In recent years, QUS has been applied in the prediction of osteoporotic fractures, in monitoring therapies, and in the investigation of secondary osteoporosis ${ }^{53}$. Several studies showed the positive correlation between calcaneal QUS and BMD of the spine or the proximal femur assessed by DXA ${ }^{52,54}$. Moreover, QUS allows us to measure the BQI that describes the bone strength independent of $\mathrm{BMD}^{55}$. In our cohort, we did not find any difference between BQI at the begiming and at the end of the study. As expected, BQI significantly correlated with both T-s and Z-s, confirming that BQI could be use as parameter to evaluate bone status. We observed that phosphaturia positiely correlated with BQI, T-s, Z-s and duration of soccer activity. However this correlation was found only at the beginning of the League. This could be explained by the fact that phosphaturia decreased at the end of the League ( $\mathrm{FC}=0.26$ ) and, even though this decreased was not significant, it appeared to be enough to change its correlations with other parameiers at the end of the League

The strength of the study is its prospective nature. Moreover, we wiil able to evaluate a complete profile of markers of bone metabolism and corretiate them with bone mass and structural integrity profile in adult football players from a singleteam. The rimit of the study is the small number of included subjects and our results should be confinmea in larger series of football players. However, this would represent a pilot study for future larger studies on such a category of athletes to adequately investigate complete bone metabolism and bone mass and structural integrity profiles by a noninvasive and reliable approach, in order to identify, together with other parameters, such as the ones recognized in the FRAX assessment ${ }^{56}$, athletes at risk for bone fragility and, consequently, reduced physical performances.

Due to our findings, we concluded that vitamin D supplementation might be suggested in adult football players during the League, in order to prevent vitamin D deficiency with consequence mineralization defects and muscle weakness, and for improving the athletic performance. 
Figure Legend:

\section{Figure 1. Correlation between 25-OHD serum levels and rate of bone, cartilage or ligament} injures.

We observed a negative correlation between vitamin D levels and numbers of bone, cartilage or ligament injures $(p=0.014)$. Thus, subjects with lower vitamin D levels had a history of higher number of injuries.

\section{References}

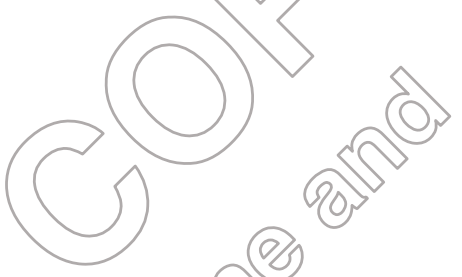

1. Dvorak J, Junge A, Graf-Baumann T, Peterson L. Football is the most popular sport worldwide. Am J Sports Med. 2004 Jan-Feb;32(1 S uppl):3S-4S. PubMied PMID: 14754853. Epub 2004/02/03.

2. Walden M, Hagglund M, Ekstrand J. injuries in Swedish elite football--a prospective study on injury definitions, risk for injury and injury pattern during 2001. Scand Med Sci Sports. 2005 Apr;15(2):118-25. PubMed PMID: 15773867. Epub 2005/03/10.

3. Hagglund M, Walden M, Ekstrand J. Exposure and injury risk in Swedish elite football: a comparison between seasons 1982 and 2001. Scand PMed Sc1 Sports. 2003 Dec;13(6):364-70. PubMed PMID: 14617057. Epub 2003/11/18.

4. Fuller CW, Ekstrand J, Junge A, Andersen TE, Bahr R, Dvorak J, et al. Consensus statement on injury definitions and data collection proeedures in studies of football (soccer) injuries. Clin J Sport Med. 2006 Mar;16(2):97-106. PubMed PMID 15503877. Epub 2006/04/11.

5. Tenforde AS, Fredericson M. Infinence of Sports participation on bone health in the young athlete: a review of the literature. EM R. 201 S Sep;3(9):861-7. PubMed PMID: 21944303. Epub 2011/09/29.

6. Alfredson H, Nordstromp, Lorentzon R. Total and regional bone mass in female soccer players. Calcif Tissue Int. 1996)Dec;59(6):438-42. PubMed PMID: 8939768. Epub 1996/12/01.

7. Karlsson MK, Hasserius R, Obrant KJ. Bone mineral density in athletes during and after career: a comparisøn between loaded and unloaded skeletal regions. Calcif Tissue Int. 1996 Oct;59(4):245-8. PubMed PMID: 8781046. Epub 1996/10/01.

8. Nordstrom P, Thorsen K, Bergstrom E, Lorentzon R. High bone mass and altered relationships between bone mass, muscle strength, and body constitution in adolescent boys on a high level of physical activity. Bone. 1996 Aug;19(2):189-95. PubMed PMID: 8853864. Epub 1996/08/01.

9. Rutherford OM. Is there a role for exercise in the prevention of osteoporotic fractures? $\mathrm{Br} \mathrm{J}$ Sports Med. 1999 Dec;33(6):378-86. PubMed PMID: 10597845. Pubmed Central PMCID: PMC1756218. Epub 1999/12/22.

10. Lanyon LE. Control of bone architecture by functional load bearing. J Bone Miner Res. 1992 Dec;7 Suppl 2:S369-75. PubMed PMID: 1485545. Epub 1992/12/01.

11. Vicente-Rodriguez G, Ara I, Perez-Gomez J, Serrano-Sanchez JA, Dorado C, Calbet JA. High femoral bone mineral density accretion in prepubertal soccer players. Med Sci Sports Exerc. 2004 Oct;36(10):1789-95. PubMed PMID: 15595302. Epub 2004/12/15. 
12. Lozano-Berges G, Matute-Llorente A, Gonzalez-Aguero A, Gomez-Bruton A, GomezCabello A, Vicente-Rodriguez G, et al. Soccer helps build strong bones during growth: a systematic review and meta-analysis. Eur J Pediatr. 2018 Mar;177(3):295-310. PubMed PMID: 29282554. Epub 2017/12/29.

13. Ferry B, Duclos M, Burt L, Therre P, Le Gall F, Jaffre C, et al. Bone geometry and strength adaptations to physical constraints inherent in different sports: comparison between elite female soccer players and swimmers. J Bone Miner Metab. 2011 May;29(3):342-51. PubMed PMID: 20963459. Epub 2010/10/22.

14. Lozano-Berges G, Matute-Llorente A, Gomez-Bruton A, Gonzalez-Aguero A, VicenteRodriguez G, Casajus JA. Bone geometry in young male and female football players: a peripheral quantitative computed tomography (pQCT) study. Arch Osteoporos. 2018 May 8;13(1):57. PubMed PMID: 29737414. Epub 2018/05/09.

15. Nikander R, Sievanen H, Uusi-Rasi K, Heinonen A, Kannus P. Loading modafities and bone structures at nonweight-bearing upper extremity and weight-bearing lower extremif9: a pQT study of adult female athletes. Bone. 2006 Oct;39(4):886-94. PubMed PMID. 16731064. Epub 2006/05/30. 16. Nilsson M, Ohlsson C, Mellstrom D, Lorentzon M. Sport-specific association between exercise loading and the density, geometry, and microstructure of weight-beanng bone in young adult men. Osteoporos Int. 2013 May;24(5):1613-22. PubMed PMID: 23011982. Pubmed Central PMCID: PMC3627855. Epub 2012/09/27.

17. Weidauer L, Minett M, Negus C, Binkłey T, Jukgvich M. Wey H, et al. Odd-impact loading results in increased cortical area and moments of inertia in collegiate atileres. Eur J Appl Physiol. 2014;114(7):1429-38. PubMed PMID: 24654495. Epub 2014/93/26.

18. Goolsby MA, Boniquit N. Bone Health in Athletes. Sports Health. 2017 Mar/Apr;9(2):10817. PubMed PMID: 27821574. Pubmed Central PMCHD PMC5349390. Epub 2016/11/09.

19. Vuolo L, Di Somma C, Faggiano A, Coiag A. Vitamin D and cancer. Front Endocrinol (Lausanne). 2012;3:58. PubMed PMID: 22649423. Pubmed Central PMCID: PMC3355893. Epub 2012/06/01.

20. Muscogiuri G, Altieri B, Penna-Martinez MS Badenhoop K. Focus on vitamin D and the adrenal gland. Horm Metab Res. 2015 Apr; 4 (4):239-46. PubMed PMID: 25723858. Epub 2015/02/28.

21. Altieri B Grant WB, Della Casa S, Orio F, Pontecorvi A, Colao A, et al. Vitamin D and pancreas: The role of sunshine itamin in the pathogenesis of diabetes mellitus and pancreatic cancer. Crit Rev Food SciNutr. 2017 Dov 2;57(16):3472-88. PubMed PMID: 27030935. Epub 2016/04/01. 22. Altieri B, Muscoginfi G, Barrea L, Mathieu C, Vallone CV, Mascitelli L, et al. Does vitamin D play a role in autoimmune endocrine disorders? A proof of concept. Rev Endocr Metab Disord. 2017 Sep:18(3):335-46. PubMed PMID: 28070798. Epub 2017/01/11.

23. Tirabassi G, Salvio G, Altieri B, Ronchi CL, Della Casa S, Pontecorvi A, et al. Adrenal disorders: Is there Any role for vitamin D? Rev Endocr Metab Disord. 2017 Sep;18(3):355-62. PubMed PMID: 27761790. Epub 2016/10/21.

24. Hossein-nezhad A, Holick MF. Vitamin D for health: a global perspective. Mayo Clin Proc. 2013 Jul;88(7):720-55. PubMed PMID: 23790560. Pubmed Central PMCID: PMC3761874. Epub 2013/06/25.

25. Holick MF. Vitamin D deficiency. N Engl J Med. 2007 Jul 19;357(3):266-81. PubMed PMID: 17634462. Epub 2007/07/20.

26. Lips P, Cashman KD, Lamberg-Allardt C, Bischoff-Ferrari HA, Obermayer-Pietsch BR, Bianchi $\mathrm{M}$, et al. MANAGEMENT OF ENDOCRINE DISEASE: Current vitamin D status in European and Middle East countries and strategies to prevent vitamin D deficiency; a position 
statement of the European Calcified Tissue Society. Eur J Endocrinol. 2019 Feb 1. PubMed PMID: 30721133. Epub 2019/02/06.

27. Bischoff-Ferrari HA, Dietrich T, Orav EJ, Hu FB, Zhang Y, Karlson EW, et al. Higher 25hydroxyvitamin $\mathrm{D}$ concentrations are associated with better lower-extremity function in both active and inactive persons aged $>$ or $=60$ y. Am J Clin Nutr. 2004 Sep;80(3):752-8. PubMed PMID: 15321818. Epub 2004/08/24.

28. Ward KA, Das G, Berry JL, Roberts SA, Rawer R, Adams JE, et al. Vitamin D status and muscle function in post-menarchal adolescent girls. J Clin Endocrinol Metab. 2009 Feb;94(2):55963. PubMed PMID: 19033372. Epub 2008/11/27.

29. Wyon MA, Wolman R, Kolokythas N, Sheriff K, Galloway S, Mattiussi A. The Effect of Vitamin D Supplementation in Elite Adolescent Dancers on Muscle Funetion and Injury Incidence: A Randomised Double-Blind Study. Int J Sports Physiol Perform. 2018 Jun 12:1-15. PubMed PMID: 29893596. Epub 2018/06/13.

30. Koundourakis NE, Androulakis NE, Malliaraki N, Margioris AN. Vitami and exercise performance in professional soccer players. PLoS One 2014.9(7): 1016593 PubMed PMID: 24992690. Pubmed Central PMCID: PMC4081585. Epub 2014/07/06.

31. Galan F, Ribas J, Sanchez-Martinez PM, Calero T, Sanchez AB. Munoz A. Serum 25hydroxyvitamin $D$ in early autumn to ensure vitaniin $D$ sufficiency in mid-winter in professional football players. Clin Nutr. 2012 Feb;31(1):132-6. PubMed PMID: 21843910. Epub 2011/08/17.

32. Kopec A, Solarz K, Majda F, Slowinska-Lisowska M, Medras M. An evaluation of the levels of vitamin $\mathrm{d}$ and bone turnover markers after the summer and winter pexiods in polish professional soccer players. J Hum Kinet. 2013;38:135-40. PubMed PMH0924232955. Pubmed Central PMCID: PMC3827761. Epub 2013/11/16.

33. Solarz K, Kopec A, Pietraszerwska J, Majda Slowinska-Lisowska M, Medras M. An evaluation of the levels of 25-hydroxyvitamin D3 and cone turnover markers in professional football players and in physically inactive men. Physio Res. 2014,63(2):237-43. PubMed PMID: 24397809. Epub 2014/01/09.

34. Hamilton B, Whiteley R, Farooq A, Chalabi H. Vitamin D concentration in 342 professional football players and assoeiation with Power limb isokinetic function. J Sci Med Sport. 2014 Jan;17(1):139-43. PubMed PMID: 23623203. Epub2013/04/30.

35. Maroon IC, Mathyssek CAM, Bost JW, Amos A, Winkelman R, Yates AP, et al. Vitamin D profile in National Fogtball League players. Am J Sports Med. 2015 May;43(5):1241-5. PubMed PMID: 25649084. Epub 2015/02/05.

36. Angelini FM, F.; Stesina, G.; Stefanini, L.; Bonuccelli, A.; Beschi, S.; Buonocore, D.; Rucci, S.; Tencone, F. Seasorial pattern of vitamin D in male elite soccer players. Journal of the International Society of Sports Nutrition. 2011;8:35.

37. Hanwell HE, Vieth R, Cole DE, Scillitani A, Modoni S, Frusciante V, et al. Sun exposure questionnaire predicts circulating 25-hydroxyvitamin D concentrations in Caucasian hospital workers in southern Italy. J Steroid Biochem Mol Biol. 2010 Jul;121(1-2):334-7. PubMed PMID: 20298782. Epub 2010/03/20.

38. Obesity. A report of the Royal College of Physicians. J R Coll Physicians Lond. 1983 Jan;17(1):5-65. PubMed PMID: 6827490. Pubmed Central PMCID: PMC5370967. Epub $1983 / 01 / 01$.

39. Yanovski SZ. A practical approach to treatment of the obese patient. Arch Fam Med. 1993 Mar;2(3):309-16. PubMed PMID: 8252152. Epub 1993/03/01.

40. Expert Panel on Detection E, Treatment of High Blood Cholesterol in A. Executive Summary of The Third Report of The National Cholesterol Education Program (NCEP) Expert Panel on 
Detection, Evaluation, And Treatment of High Blood Cholesterol In Adults (Adult Treatment Panel III). JAMA. 2001 May 16;285(19):2486-97. PubMed PMID: 11368702. Epub 2001/05/23.

41. Holick MF, Binkley NC, Bischoff-Ferrari HA, Gordon CM, Hanley DA, Heaney RP, et al. Evaluation, treatment, and prevention of vitamin D deficiency: an Endocrine Society clinical practice guideline. J Clin Endocrinol Metab. 2011 Jul;96(7):1911-30. PubMed PMID: 21646368. Epub 2011/06/08.

42. Gudmundsdottir SL, Indridason OS, Franzson L, Sigurdsson G. Age-related decline in bone mass measured by dual-energy X-ray absorptiometry and quantitative ultrasound in a populationbased sample of both sexes: identification of useful ultrasound thresholds for osteoporosis screening. J Clin Densitom. 2005 Spring;8(1):80-6. PubMed PMID: 15722591. Epub 2005/02/22.

43. Arnason A, Sigurdsson SB, Gudmundsson A, Holme I, Engebretsen L, Bahr R. Risk factors for injuries in football. Am J Sports Med. 2004 Jan-Feb;32(1 Suppi):5S-16S. PubMed PMID: 14754854. Epub 2004/02/03.

44. Eirale C, Volpi P, Bisciotti GN. Injury epidemiology in Italian soccer: a @al for action. J Sports Med Phys Fitness. 2018 Oct;58(10):1554-5. PubMed PMID: 29199790. Epub 2017/12/05.

45. Peterson L, Junge A, Chomiak J, Graf-Baumann T, D vorak J. Incidence of football injuries and complaints in different age groups and skill-level groups. Am Jo Sports Med. 2000;28(5 Suppl):S51-7. PubMed PMID: 11032108. Epub 2000/10/14.

46. Giza E, Mithofer K, Farrell L, Zarins B, Gili T. Injuries in wornen's professional soccer. Br J Sports Med. 2005 Apr;39(4):212-6; discussion -6. PubMed RMN13. 15793089. Pubmed Central PMCID: PMC1725176. Epub 2005/03/29.

47. Morton JP, Iqbal Z, Drust B, Burgess D, Close GL, Brukner PDPEeasonal variation in vitamin D status in professional soccer players of the English Premier Legue. Appl Physiol Nutr Metab. 2012 Aug;37(4):798-802. PubMed PMID: 22554144 Epon 2013\%105/05.

48. Wicherts IS, van Schoor NM, Boeke AJ, risser M Deeg DJ, Smit J, et al. Vitamin D status predicts physical performance and its, decline in - older persons. J Clin Endocrinol Metab. 2007 Jun;92(6):2058-65. PubMed PMID: 17341569. Epub 2003/103/08.

49. Houston DK, Cesari M, Ferrucci D, Cherubini A, Maggio D, Bartali B, et al. Association between vitamin D status and physical ferformance: the InCHIANTI study. J Gerontol A Biol Sci Med Sci. 2007 Apr;62 (4):440-6. Pub11ed PMHD:17452740. Pubmed Central PMCID: PMC2645652. Epub 2007/04/25.

50. Visser M Deeg DJ, Lips (P), Longitudinal Aging Study A. Low vitamin D and high parathyroid hormone levels as determinants of loss of muscle strength and muscle mass (sarcopenia): the Longitudinal Aging Study Atmsterdam. J Clin Endocrinol Metab. 2003 Dec;88(12):5766-72. PubMed PMID: 14671166. Epub 2003/12/13.

51. Close GL, Leckey J, Patterson M, Bradley W, Owens DJ, Fraser WD, et al. The effects of vitamin $\mathrm{D}(3)$ supplementation on serum total $25[\mathrm{OH}] \mathrm{D}$ concentration and physical performance: a randomised dose-response study. Br J Sports Med. 2013 Jul;47(11):692-6. PubMed PMID: 23410885. Epub 2013/02/16.

52. Brahm H, Strom H, Piehl-Aulin K, Mallmin H, Ljunghall S. Bone metabolism in endurance trained athletes: a comparison to population-based controls based on DXA, SXA, quantitative ultrasound, and biochemical markers. Calcif Tissue Int. 1997 Dec;61(6):448-54. PubMed PMID: 9383270. Epub 1998/02/12.

53. Madsen OR, Sorensen OH, Egsmose C. Bone quality and bone mass as assessed by quantitative ultrasound and dual energy $\mathrm{x}$ ray absorptiometry in women with rheumatoid arthritis: relationship with quadriceps strength. Ann Rheum Dis. 2002 Apr;61(4):325-9. PubMed PMID: 11874835. Pubmed Central PMCID: PMC1754061. Epub 2002/03/05. 
1

54. Faulkner KG, McClung MR, Coleman LJ, Kingston-Sandahl E. Quantitative ultrasound of the heel: correlation with densitometric measurements at different skeletal sites. Osteoporos Int. 1994 Jan;4(1):42-7. PubMed PMID: 8148571. Epub 1994/01/01.

55. Licata A. Bone density vs bone quality: what's a clinician to do? Cleve Clin J Med. 2009 Jun;76(6):331-6. PubMed PMID: 19487553. Epub 2009/06/03.

56. Kanis JA, Johnell O, Oden A, Johansson H, McCloskey E. FRAX and the assessment of fracture probability in men and women from the UK. Osteoporos Int. 2008 Apr;19(4):385-97. PubMed PMID: 18292978. Pubmed Central PMCID: PMC2267485. Epub 2008/02/23. 
Table 1. Clinical, biochemical and densitometric parameters in 16 professional male football players at the beginning and the end of league.

\begin{tabular}{|c|c|c|c|c|}
\hline \multirow[t]{2}{*}{ Parameters } & \multicolumn{2}{|c|}{ Mean \pm SD } & \multirow{2}{*}{ Normal range } & \multirow[t]{2}{*}{$p$} \\
\hline & Beginning & End & & \\
\hline $\mathrm{SBP}(\mathrm{mmHg})$ & $111.8 \pm 10.8$ & $11.8 \pm 10.8$ & & ns \\
\hline $\mathrm{DBP}(\mathrm{mmHg})$ & $76.8 \pm 9.5$ & $75.0 \pm 9.2$ & & ns \\
\hline Hight $(\mathrm{cm})$ & $176.2 \pm 7.6$ & - & & - \\
\hline Weight $(\mathrm{kg})$ & $69.0 \pm 8.2$ & $69.2 \pm 7.4$ & & ns \\
\hline $\operatorname{BMI}\left(\mathrm{kg} / \mathrm{m}^{2}\right)$ & $22.1 \pm 1.3$ & $22.2 \pm 1.1$ & & ns \\
\hline $\mathrm{WC}(\mathrm{cm})$ & $81.9 \pm 4.4$ & $81.8 \pm 4.4$ & $75-90$ & ns \\
\hline Serum albumin $(g / L)$ & $45+a$ & & $4-5$ & ns \\
\hline Serum creatinine (mg/dl) & & $1.0 \pm 0$. & $20.9-1.3$ & ns \\
\hline Creatinine clearance $(\mathrm{ml} / \mathrm{min})$ & & & $67-107$ & ns \\
\hline Serum 25-OHD (ng/ml) & & $27.1 \pm$ & $30-100$ & 0.008 \\
\hline Serum ALP (U/L) & & $11001+37.7$ & $71-140$ & ns \\
\hline Serum iPTH $(\mathrm{pg} / \mathrm{ml})$ & $18.6 \pm 5.5$ & $21.4 \pm 24.4$ & $11-31$ & $\mathrm{~ns}$ \\
\hline Serum calcium $(\mathrm{mg} / \mathrm{d} /)$ & & $9.9 \pm 0.5$ & $9.2-10.5$ & ns \\
\hline Serum phosphorùs (mg/di) & $4.0 \pm 0.5$ & $4.0 \pm 0.4$ & $3.1-4.9$ & ns \\
\hline Urinary calcium (mg/24h) & $151.6 \pm 59.4$ & $168.5 \pm 92.1$ & $51-260$ & ns \\
\hline Urinary phosphorus (mg/24hin & $934.0 \pm 274.3$ & $691.0 \pm 364.5$ & $350-1575$ & ns \\
\hline Calcaneal ultrasonometer T-s & $1.7 \pm 1.1$ & $1.6 \pm 1.0$ & $0.2-3.4$ & ns \\
\hline Calcaneal ultrasonometer Z-s & $1.7 \pm 1.1$ & $1.6 \pm 1.0$ & $0.2-3.4$ & ns \\
\hline BQI (right feet) & $138.5 \pm 17.7$ & $133.7 \pm 15.3$ & $0-150$ & ns \\
\hline
\end{tabular}

Abbreviation: 25-OHD: 25-hydroxyvitamin D; ALP: total alkaline phosphatase; BMI: body mass index; BQI: bone quality index; DBP: diastolic blood pressure; iPTH: parathyroid hormone; ns: $p$ not statistically significant; SBP: systolic blood pressure; T-s: T-score of the calcaneus; WC: waist circumference; Z-s: Z-score of the calcaneus; -: not applicable. 
Bone metabolism, bone mass and structural integrity profile in professional male football players.

Mariagiovanna Filippella ${ }^{1,2}$, Barbara Altieri ${ }^{3}$, Alberto Falchetti ${ }^{4}$, Roberta Cosso ${ }^{4}$, Hellas Cena ${ }^{5}$, Corrado Musso $^{6}$, Erica Geronutti ${ }^{1}$, Luciano Rassat $^{1}$, Giulia Cipriani ${ }^{7}$, Annamara Colao $^{3}$, Carolina Di Somma $^{3}$, Antongiulio Faggiano ${ }^{8}$.

${ }^{1}$ Medicine and Rehabilitation Clinical Institute of Aosta, Italy.

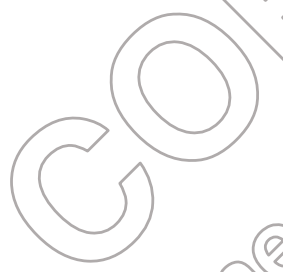

${ }^{2}$ Nutrition and Metabolism Unit, Humanitas Gavezzani, Bergamo, Italy.

${ }^{3}$ Department of Clinical Medicine and Surgery, Federice II University of vaples, Naples, Italy.

${ }^{4}$ EndOsMet Division, Branch of Metabolic Bone Diseases, MiPa) Donatello Private Hospital, Florence, and Service of Endocrinology and Bone Metabolism Disease Herciblani Centre of Bologna, Italy.

${ }^{5}$ Department of Public Health, Experimental Medicine and Forensic, Unit of Food Sciences University of Pavia, Italy.

${ }^{6}$ Unit of Neurosurgery Humanitas of Bergam arid Pelycininc of Monza, Italy.

${ }^{7}$ Sangro Health Systern, L) Aquila, Italy.

${ }^{8}$ Department of Experimental Medicine, Sapienza University of Rome, Rome, Italy.

Short Title: Bone metabolism and hypovitaminosis D in football players.

Conflict of interest: the authors declare that they have no conflicts of interest.

\section{Corresponding Author:}

Altieri Barbara, MD, PhD

Department of Clinical Medicine and Surgery,

Federico II University of Naples,

Via Sergio Pansini 5, 82121,

Naples, Italy. 


\begin{abstract}
BACKGROUND: Physical exercise plays an important role in bone mineralization as well as factors involved in bone metabolism influence the athletic performance. In European countries, soccer is the most popular sport. The aim of the study was to investigate bone metabolism, bone mass and structural integrity profile in professional male adult football players.

METHODS: Sixteen professional male football players from a single team of the 2nd division Italian League (mean age 22.4 \pm 0.7 years) were enrolled. Bone biochemical parameters, ineruding serum calcium, phosphorus, albumin, creatinine, alkaline phosphatase, intact plasmagTH, 25-hydroxyvitamin D (25-OHD), 24-h urinary calcium and phosphorus, and calcaneaf quantitative ultrasound (QUS), were evaluated at the beginning (October 2012), and at the eng of the League (May 2013).
\end{abstract}

RESULTS: 25-OHD levels were significantly lower at the end of the Peague compared to the beginning (27.1 \pm 5.9 vs $36.6 \pm 9.5 \mathrm{ng} / \mathrm{ml}$, fold change $(\mathrm{F} C)=0.25,0=0.008)$, and the prevalence of 25-OHD deficiency increased from 25 to $73 \%$. Mreaver, higher rate of previous bone, cartilage or ligament injuries correlated with 25-OHD deficiencies ( $(B)=0.014)$. T-score and Z-score were at the upper limits of the normality ranges, without significant difference between the beginning and end of the League. Phosphaturia was slightiy decreased at the end of the League [(691.0 2364.5 vs $934.0 \pm$ $274.3 \mathrm{mg} / 2411, \mathrm{FC}=0.26, p=0.06)]$. A significant correlation was found between phosphaturia and $\mathrm{BQI}(\mathrm{R}$ square $=0.28, p=0.03)$, and both $\mathrm{T}-\mathrm{s}$ and $\mathrm{Z}-\mathrm{s}(\mathrm{R}$ square $=0.28, p=0.03)$ at the beginning of the League.

CONCLUSIONS: With this pilot study, we demonstrated that vitamin D status significantly worsened at the end of the League. Therefore, vitamin D supplementation might be suggested in adult football players in order to prevent vitamin D deficiency and improve the athletic performance.

Key Words: Bone turnover; Bone Mineral Density; vitamin D; football players. 


\section{Introduction}

Soccer is the worldwide most popular sport, with about 200 million players, both professionals and amateurs ${ }^{1}$. Several risk factors for soccer injuries have been described ${ }^{2}$, including 1) the level of play, the risk appears to be higher in professional than amateur players; 2) the exercise load; and 3) the standard of training ${ }^{3}$. The main types of injury are traumatic, such as fracture, contusion or hematoma, laceration, muscle or tendon strain and joint or ligament sprains and/or overuse, injuries ${ }^{4}$. To the other side, sports with high impact or odd-impact loading, including soccers are associated with higher bone mineral composition and bone mineral density (BMD) ${ }^{5}$. Many studies reported that the increased BMD in athletes was mainly due to the strain resulting fromimpact bone loading, rather than, and independently from, muscle strength increase ${ }^{6}$. However. most st in girls and only occasionally in men 7,8 . Exercise seems tog have benefictal effects on bone tissue by stimulating the osteogenic responses 9,10 . Soccer is sharacterized by various types of running with rapid changes of direction, starts, stops, jumping, and kicking resulting in large ground reaction forces at the skeleton, and thus can be classified as angmpact loading sport ${ }^{6}$. Several studies have demonstrated that soceer have a positive effects on bone mass and those effects are greatest during growth 5, 11,12. However, this effect on bone health could be explained not only to an improvement of BMD, but also to an improvement of bone geometry, evaluated by with peripheral quantitative computed tomography or hip structural analysis ${ }^{13,14}$. Different studies demonstrated that young adult soccer players had better bone geometry, including cortical area, periosteal circumference and volumetric bone mineral density, than matched controls in both genders ${ }^{15-17}$.

A crucial role in bone health and mineralization is played by Vitamin D, due its role in the regulation of calcium and phosphorus metabolism ${ }^{18}$. Vitamin D deficiency is a worldwide health problem ${ }^{19-23}$ and it is associated with impaired neuromuscular function, bone loss and fractures ${ }^{24-26}$. More specifically, it has been shown that vitamin D levels correlate with grip and quadriceps strength, 
physical fitness, and prevent falls and bone fractures ${ }^{27}$. Particularly, vitamin D deficiency predominantly affects the weight-bearing antigravity muscles of the lower limbs, which are necessary for walking and postural balance ${ }^{27,28}$, explained its role in preventing falls. Furthermore, vitamin D supplementation seems to boost muscular strength and restores balance ${ }^{28-30}$. Previous studies, on different small sized football players' populations from different European Countries, have been published regarding possible relationship between seasonal variation of serum vitamin D levels and bone turnover markers (BTMs), body mass, body composition, total body water, tat-1ree mass, muscle mass, exercise performance such as squat jump, countermovement jump,10 and 20 meters sprint performance, maximal oxygen consumption (VQ2max), anthropometry, lower limb isokinetic function, race, fracture history, and the ability to obtain a contract position ${ }^{30-35}$. However, in the Italian population, only a single study on twenty-three football players evaluated the possible correlation between seasonal vitamin D levels and dual x-ray absorptiometry (DXA)-measured bone mineral content (BMC) ${ }^{36}$. The authers found that both vitanin D levels and BMC significantly decreased from autumn to winter, indicating that supplementation of vitamin D might be necessary during the winter period 36 However, the authors did inot evaluate other parameters involved in bone metabolism, including phosphorus, albumin, creatinine, alkaline phosphatase, parathyroid hormone $(\mathrm{PTH})$, as weil as they did notevaluate the bone structural integrity profile.

The aim of our study was to investigate the correlation between bone metabolism markers with bone mass and structural integrity profile in a professional male adult football players from a single team. Therefore, we evaluated also whether the rate of previous bone, cartilage or ligament injuries could be correlate with vitamin $\mathrm{D}$ deficiencies. 


\section{Patients and Methods}

\section{Patients}

Sixteen professional male football players of the S.C. Vallée d'Aoste, a 2nd division Italian club (mean age 22.4 \pm 0.7 years, range 19-28 years), were enrolled and evaluated at the beginning (October 2012) and at the end of the league (May 2013). The study protocol was approved by the local ethics committee institutional board and was carried out in accordance with the ethical standards laid down in the 1964 Declaration of Helsinki as revised in 2000. Informed consent was obtained from all the subjects included in this study. All subjects were placed on astandardized diet witis greater than 1000 mg elemental calcium per day starting 2 months before the beginning of the study. None of the participants had been taking vitamin D supplements or arugs known togterfere with bone or mineral metabolism for the last 12 months. The sun exposure, evaluated by usingaself-report questionnaire 37, was less than 10 hours/week for al1 participants. This could be explained by the fact that Valle d'Aosta is a mountain region sited in the Italian a ips where weather is generally cold, rainy and snowy, especially in autumn and winter, and that footbait players trained mostly indoors. Exclusion criteria were acute or chronic conditions that affest nîneral metabolism or complete immobilization.

\section{Clinical characteristics assessment}

Height, weight, body rass index (BMI), systolic blood pressure (SBP) and diastolic blood pressure (DBP) were evaluated by standard methods. Exercise duration was also assessed. BMI was measured as the ratio between the weight and the square of the height. A BMI between 25 and $30 \mathrm{Kg} / \mathrm{m}^{2}$ indicated a condition of over-weight, whereas BMI greater than $30 \mathrm{Kg} / \mathrm{m}^{2}$ indicated a condition of obesity ${ }^{38}$. Waist circumference (WC) was measured to the nearest $0.1 \mathrm{~cm}$ at the end of a normal expiration by measuring from the narrowest point between the lower borders of the rib cage and the iliac crest. The measurement were performed with the patients in standing position with relaxed 
abdomen, arms at sides, and joined feet ${ }^{39}$. Blood pressure was measured in the right arm, with the subjects in a relaxed sitting position. The average of 6 measurements ( 3 taken by each of 2 examiners) with a mercury sphygmomanometer was used. Arterial blood hypertension was diagnosed when DBP values were $\geq 85 \mathrm{mmHg}$ and SBP values were $\geq 130 \mathrm{mmHg}$ in line with Adult Treatment Panel III 40.

\section{Biochemical assessment}

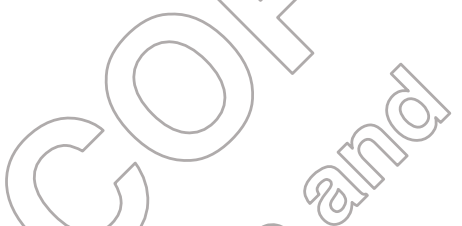

From 08:00 to 08:30 am, venous blood samples were obtained following a ten-minute period of rest in a lying position, after 12 hours-fasting, in order to determine the concertitgation of all biochemical parameters. Serum concentrations of creatinine, cailcium, phosphorus, albumin, total alkaline phosphatase (ALP) were determined at fasting by automated technique\& (Roche Modular System). Serum concentrations of intact parathyoid hormones(ipTH) were measured by electrochemiluminescence immunoassay concent ation. Sexum concentrations of 25-hydroxyvitamin D (25-OHD) were measured with direct radiojinmunoassay. According to the Endocrine Society guidelines ${ }^{41}$, a condition of vitamin $D$ insufficiency was defined by a serum concentration of 25 OHD between 20-30 $\mathrm{ng} / \mathrm{ml}$, while a condition of vitamin $\mathrm{D}$ deficiency was defined by serum concentrations of $25-\mathrm{OHD}$ below $20 \mathrm{ng} / \mathrm{ml}$. 24-h urine samples were analyzed for urinary calcium and phosphorus measurements. Creatinine clearance was also determined.

\section{Calcaneal quantitative ultrasound measurement and radiographic calcaneal examination}

Quantitative ultrasound (QUS) of the calcaneus was performed using the Sahara clinical bone sonometer (Hologic INC, USA). The calcaneus of participants was placed between two ultrasound transducers that are positioned on opposite sides to each other. This device provides measures of the velocity and frequency attenuation of the sound wave propagation through bone by the "speed of 
sound" (SOS; $\mathrm{m} / \mathrm{s}$ ) and the "broadband ultrasound attenuation" (BUA; $\mathrm{dB} / \mathrm{MHz}$ ) of an ultrasound beam passed through the calcaneus between the two transducers, and the "quantitative ultrasound index" (QUI), which is a combination between SOS and BUA. These two parameters reflect different bone properties, including density, elasticity and microarchitecture ${ }^{42}$. Bone mineral density (BMD), T-score (T-s) and Z-score (Z-s) were derived from the manufacturer reference database and provided by the software device. The QUI is converted directly by Sahara software in "bone quality index" (BQI), an assessment of calcaneus BMD $\left(\mathrm{g} / \mathrm{cm}^{2}\right)$. BQI is easy to interpret and indicates bone composition and structure. Its normal range is between 0 to 150 .

\section{Statistical Analysis}

Numerical data are expressed as mean \pm standard deviation (SD). Due the mall sample size and the non-normally-distributed data, differences between the experinental periods in the measured parameters were analyzed by the non-parametric and a linear correlation analysis by calculating the Pearsen's coefficient were performed. Values of $p<0.05$ were considered statistically significant. Statistical analysis was performed with SPSS statistical software package (version, 20.0, SPS S; Chicago, IL).

\section{Results}

Clinical, biochemical and BMD parameters both at the beginning and at the end of the League were summarized in Table 1. At the beginning of the League all evaluated parameter were within the normal range (Table 1).

Phosphaturia was slightly but not significantly decreased at the end compared to the beginning of the League $[(691.0 \pm 364.5$ vs $934.0 \pm 274.3 \mathrm{mg} / 24 \mathrm{~h}$, fold change $(\mathrm{FC})=0.26, p=0.06)]$, while serum calcium, phosphorus and iPTH as well as calciuria were unchanged (Table 1). 25-OHD serum levels 
were significantly reduced at the end of the League in comparison to the beginning $(27.1 \pm 5.9 v s$ $36.6 \pm 9.5 \mathrm{ng} / \mathrm{ml}, \mathrm{FC}=0.25, p=0.008)$. In parallel, the prevalence of $25-\mathrm{OHD}$ deficiency increased from 25 to $73 \%$ at the end of the League. The rate of previous bone, cartilage or ligament injuries correlated with the 25-OHD deficiencies $(p=0.014)$ (Figure 1). Particularly, subjects with lower vitamin D levels had a history of higher number of injuries.

No significant differences between the beginning and the end of the League were observed for BQI $(138.5 \pm 17.7$ vs $133.7 \pm 15.3, \mathrm{FC}=0.03, p=0.45), \mathrm{T}$-s and $\mathrm{Z}$-s (in beth cases, $1.7 \pm 1.1 \mathrm{~T} s \mathrm{~s} .6 \pm 1.0$, $\mathrm{FC}=0.05, p=0.48$ ), which were at the upper limits of normal range. BOI significantly correlate with both T-s and Z-s $(r=1, \mathrm{R}$ square $=0.99, p<0.001)$ at the two tume-points of the study. Interestingly, a significant positive correlation was found between phosphaturia and gone parameters, including BQI ( R square $=0.28, p=0.03$ ), and both T-s and $\mathrm{Z}-\mathrm{s}$ ( $\mathrm{R}$ square $=0.28, p=0.03$, rar Both) at the beginning of the League. Moreover, phosphaturia also signiticantly correlated with the duration of soccer activity ( $\mathrm{R}$ square $=0.68, p=0.0005$ ). A trend of positive corratition was also demonstrated between both T-s and Z-s and the duration of soccer activity ( $R$ square $=0.23, p=0.09)$ and calciuria $(\mathrm{R}$ square $=0.24$, $p=0.052$ ). However, these trends were observed only at the beginning of the League, whereas were not found after its end.

\section{Discussion and conciusiens}

The greater frequency of football accidents in recent years across all sectors, both professional and amateur ${ }^{43,44}$, youth football ${ }^{45}$ and women's football ${ }^{46}$, has been the subject of several studies and publications. Many accidents are unforeseeable as they are the natural consequences of sport in which speed, strength and explosive action are accompanied by physical contact, tackling and collisions with an opponent. Many others, however, could be avoided because they stem from mistakes, underestimation of the risk factors, or insufficient consideration of the ways in which they can be 
prevented. One risk factor could be represented by vitamin D deficiency, which impairs bone loss, neuromuscular function and postural balance, increasing the risk of fractures ${ }^{24-28}$. Morton et al. ${ }^{47}$ demonstrated a significant reduction in serum levels of 25-OHD in a group of professional soccer players of the English Premier League at the latitude of $53^{\circ} \mathrm{N}$ between the summer and the winter period (in August and December). Similarly, a study in Spanish professionar-soccer players who trained at the latitude of $37^{\circ} \mathrm{N}$ showed a statistically significant reduction in serum levels of 25-OHD between these two time periods (October and February) ${ }^{31}$. Moregver, several studies have shown a considerable correlation of vitamin D levels with muscle stracture and sirength $31,48,49$. Visser et al. ${ }^{50}$ found that a $25-\mathrm{OHD}$ level of $30 \mathrm{ng} / \mathrm{ml}$ guarantees optimal muscle function. Close et al ${ }^{51}$ suggest that decreased vitamin D levels are one of the important causes of seduced exercise capabilities in athletes.

In accordance with previous studies 31.47 we observed that 25 -OHE serum levels were significantly reduced at the end of the League as compared to the beginning, as well as the prevalence of 25-OHD deficiency according to the Endocrine Society gurdelinest) increased from 25 to $73 \%$. We also found that the rate of previous bone, cartilage of itigamentinifuries correlated with the 25-OHD deficiencies, indicating that vitainin Dyight contribute to the correction function of musculoskeletal system. Conflicting resilts on the impact of physical activity on serum of PTH are reported in the literature. Particularly, it has been shown that in athletes pursuing performance disciplines, serum levels of PTH were lower than in physically inactive subjects ${ }^{52}$. In our study we did not observed any differences in PTH levels during the beginning and the end of the League. Only phosphaturia was slightly but not significantly decreased at these two time points.

Bone mass status was evaluated using the QUS method. Different from the DXA, which remains the gold standard technique for measuring the BMD, QUS is an attractive alternative method of bone assessment because it is a non-invasive technique, radiation-free, low-cost, simple, and is portable. 
In recent years, QUS has been applied in the prediction of osteoporotic fractures, in monitoring therapies, and in the investigation of secondary osteoporosis ${ }^{53}$. Several studies showed the positive correlation between calcaneal QUS and BMD of the spine or the proximal femur assessed by DXA 52, 54. Moreover, QUS allows us to measure the BQI that describes the bone strength independent of $\mathrm{BMD}^{55}$. In our cohort, we did not find any difference between BQI at the beginning and at the end of the study. As expected, BQI significantly correlated with both T-s and Z-s, confirming that BQI could be use as parameter to evaluate bone status. We observed that phosphaturia positiely correlated with BQI, T-s, Z-s and duration of soccer activity. However this correlation was found only at the beginning of the League. This could be explained by the fact that phosphaturia decreased at the end of the League ( $\mathrm{FC}=0.26)$ and, even though this decreased was not siggificant, it appeared to be enough to change its correlations with other parameters at the end of the League

The strength of the study is its prospective nature. Moreover, we will able to evaluate a complete profile of markers of bone metabolism and corretate them with bone mass and structural integrity profile in adult football players from a singleteam. Thes init of the study is the small number of included subjects and our results should be confinmea in larger series of football players. However, this would represent a pilot study for future larger studies on such a category of athletes to adequately investigate complete bone metabolism and bone mass and structural integrity profiles by a noninvasive and reliable approach, in order to identify, together with other parameters, such as the ones recognized in the FRAX assessment ${ }^{56}$, athletes at risk for bone fragility and, consequently, reduced physical performances.

Due to our findings, we concluded that vitamin D supplementation might be suggested in adult football players during the League, in order to prevent vitamin D deficiency with consequence mineralization defects and muscle weakness, and for improving the athletic performance. 
Figure Legend:

\section{Figure 1. Correlation between 25-OHD serum levels and rate of bone, cartilage or ligament} injures.

We observed a negative correlation between vitamin D levels and numbers of bone, cartilage or ligament injures $(p=0.014)$. Thus, subjects with lower vitamin D levels had a history of higher number of injuries.

\section{References}

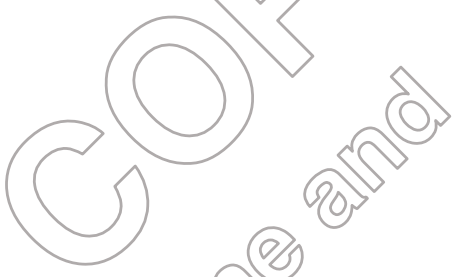

1. Dvorak J, Junge A, Graf-Baumann T, Peterson L. Football is the most popular sport worldwide. Am J Sports Med. 2004 Jan-Feb;32(1 S uppl):3S-4S. PubMied PMID: 14754853. Epub 2004/02/03.

2. Walden M, Hagglund M, Ekstrand J. injuries in Swedish elite football--a prospective study on injury definitions, risk for injury and injury pattern during 2001. Scand Med Sci Sports. 2005 Apr;15(2):118-25. PubMed PMID: 15773867. Epub 2005/03/10.

3. Hagglund M, Walden M, Ekstrand J. Exposure and injury risk in Swedish elite football: a comparison between seasons 1982 and 2001. Scand PMed Sc1 Sports. 2003 Dec;13(6):364-70. PubMed PMID: 14617057. Epub 2003/11/18.

4. Fuller CW, Ekstrand J, Junge A, Andersen TE, Basg R, Dvorak J, et al. Consensus statement on injury definitions and data collection proeedures in studies of football (soccer) injuries. Clin $\mathbf{J}$ Sport Med. 2006 Mar;16(2):97-106. PubMed PMID 15503877. Epub 2006/04/11.

5. Tenforde AS, Fredericson M. Infinence of Sports participation on bone health in the young athlete: a review of the literature. RM R. 201 S Sep;3(9):861-7. PubMed PMID: 21944303. Epub 2011/09/29.

6. Alfredson H, Nordstromp, Lorentzon R. Total and regional bone mass in female soccer players. Calcif Tissue Int. 1996)Dec;59(6):438-42. PubMed PMID: 8939768. Epub 1996/12/01.

7. Karlsson MK, Hasserius R, Obrant KJ. Bone mineral density in athletes during and after career: a comparisøn between loaded and unloaded skeletal regions. Calcif Tissue Int. 1996 Oct;59(4):245-8. PubMed PMID: 8781046. Epub 1996/10/01.

8. Nordstrom P, Thorsen K, Bergstrom E, Lorentzon R. High bone mass and altered relationships between bone mass, muscle strength, and body constitution in adolescent boys on a high level of physical activity. Bone. 1996 Aug;19(2):189-95. PubMed PMID: 8853864. Epub 1996/08/01.

9. Rutherford OM. Is there a role for exercise in the prevention of osteoporotic fractures? $\mathrm{Br} \mathrm{J}$ Sports Med. 1999 Dec;33(6):378-86. PubMed PMID: 10597845. Pubmed Central PMCID: PMC1756218. Epub 1999/12/22.

10. Lanyon LE. Control of bone architecture by functional load bearing. J Bone Miner Res. 1992 Dec;7 Suppl 2:S369-75. PubMed PMID: 1485545. Epub 1992/12/01.

11. Vicente-Rodriguez G, Ara I, Perez-Gomez J, Serrano-Sanchez JA, Dorado C, Calbet JA. High femoral bone mineral density accretion in prepubertal soccer players. Med Sci Sports Exerc. 2004 Oct;36(10):1789-95. PubMed PMID: 15595302. Epub 2004/12/15. 
12. Lozano-Berges G, Matute-Llorente A, Gonzalez-Aguero A, Gomez-Bruton A, GomezCabello A, Vicente-Rodriguez G, et al. Soccer helps build strong bones during growth: a systematic review and meta-analysis. Eur J Pediatr. 2018 Mar;177(3):295-310. PubMed PMID: 29282554. Epub 2017/12/29.

13. Ferry B, Duclos M, Burt L, Therre P, Le Gall F, Jaffre C, et al. Bone geometry and strength adaptations to physical constraints inherent in different sports: comparison between elite female soccer players and swimmers. J Bone Miner Metab. 2011 May;29(3):342-51. PubMed PMID: 20963459. Epub 2010/10/22.

14. Lozano-Berges G, Matute-Llorente A, Gomez-Bruton A, Gonzalez-Aguero A, VicenteRodriguez G, Casajus JA. Bone geometry in young male and female football players: a peripheral quantitative computed tomography (pQCT) study. Arch Osteoporos. 2018 May 8;13(1):57. PubMed PMID: 29737414. Epub 2018/05/09.

15. Nikander R, Sievanen H, Uusi-Rasi K, Heinonen A, Kannus P. Loading modafities and bone structures at nonweight-bearing upper extremity and weight-bearing lower extremif9: a pQT study of adult female athletes. Bone. 2006 Oct;39(4):886-94. PubMed PMID. 16731064. Epub 2006/05/30. 16. Nilsson M, Ohlsson C, Mellstrom D, Lorentzon M. Sport-specific association between exercise loading and the density, geometry, and microstructure of weight-beanng bone in young adult men. Osteoporos Int. 2013 May;24(5):1613-22. PubMed PMID: 23011982. Pubmed Central PMCID: PMC3627855. Epub 2012/09/27.

17. Weidauer L, Minett M, Negus C, Binkłey T, Jukgvich M. Wey H, et al. Odd-impact loading results in increased cortical area and moments of inertia in collegiate atileres. Eur J Appl Physiol. 2014;114(7):1429-38. PubMed PMID: 24654495. Epub 2014/93/26.

18. Goolsby MA, Boniquit N. Bone Health in Athletes. Sports Health. 2017 Mar/Apr;9(2):10817. PubMed PMID: 27821574. Pubmed Central PMCHD PMC5349390. Epub 2016/11/09.

19. Vuolo L, Di Somma C, Faggiano A, Colág A. Vitamin D and cancer. Front Endocrinol (Lausanne). 2012;3:58. PubMed PMID: 22649423. Pubmed Central PMCID: PMC3355893. Epub 2012/06/01.

20. Muscogiuri G, Altieri B, Penna-Martinez MS Badenhoop K. Focus on vitamin D and the adrenal gland. Horm Metab Res. 2015 Apr;A 7 (4):239-46. PubMed PMID: 25723858. Epub 2015/02/28.

21. Altieri B Grant WB, Della Casa S, Orio F, Pontecorvi A, Colao A, et al. Vitamin D and pancreas: The role of sunshine itamin in the pathogenesis of diabetes mellitus and pancreatic cancer. Crit Rev Food SciNutr. 2017 Dov 2;57(16):3472-88. PubMed PMID: 27030935. Epub 2016/04/01. 22. Altieri B, Muscoginfi G, Barrea L, Mathieu C, Vallone CV, Mascitelli L, et al. Does vitamin D play a role in autoimmune endocrine disorders? A proof of concept. Rev Endocr Metab Disord. 2017 Sep:18(3):335-46. PubMed PMID: 28070798. Epub 2017/01/11.

23. Tirabassi G, Salvio G, Altieri B, Ronchi CL, Della Casa S, Pontecorvi A, et al. Adrenal disorders: Is there Any role for vitamin D? Rev Endocr Metab Disord. 2017 Sep;18(3):355-62. PubMed PMID: 27761790. Epub 2016/10/21.

24. Hossein-nezhad A, Holick MF. Vitamin D for health: a global perspective. Mayo Clin Proc. 2013 Jul;88(7):720-55. PubMed PMID: 23790560. Pubmed Central PMCID: PMC3761874. Epub 2013/06/25.

25. Holick MF. Vitamin D deficiency. N Engl J Med. 2007 Jul 19;357(3):266-81. PubMed PMID: 17634462. Epub 2007/07/20.

26. Lips P, Cashman KD, Lamberg-Allardt C, Bischoff-Ferrari HA, Obermayer-Pietsch BR, Bianchi $\mathrm{M}$, et al. MANAGEMENT OF ENDOCRINE DISEASE: Current vitamin D status in European and Middle East countries and strategies to prevent vitamin D deficiency; a position 
statement of the European Calcified Tissue Society. Eur J Endocrinol. 2019 Feb 1. PubMed PMID: 30721133. Epub 2019/02/06.

27. Bischoff-Ferrari HA, Dietrich T, Orav EJ, Hu FB, Zhang Y, Karlson EW, et al. Higher 25hydroxyvitamin $\mathrm{D}$ concentrations are associated with better lower-extremity function in both active and inactive persons aged $>$ or $=60$ y. Am J Clin Nutr. 2004 Sep;80(3):752-8. PubMed PMID: 15321818. Epub 2004/08/24.

28. Ward KA, Das G, Berry JL, Roberts SA, Rawer R, Adams JE, et al. Vitamin D status and muscle function in post-menarchal adolescent girls. J Clin Endocrinol Metab. 2009 Feb;94(2):55963. PubMed PMID: 19033372. Epub 2008/11/27.

29. Wyon MA, Wolman R, Kolokythas N, Sheriff K, Galloway S, Mattiussi A. The Effect of Vitamin D Supplementation in Elite Adolescent Dancers on Muscle Funetion and Injury Incidence: A Randomised Double-Blind Study. Int J Sports Physiol Perform. 2018 Jun 12:1-15. PubMed PMID: 29893596. Epub 2018/06/13.

30. Koundourakis NE, Androulakis NE, Malliaraki N, Margioris AN. Vitami and exercise performance in professional soccer players. PLoS One 2014:9(7): 101659 PubMed PMID: 24992690. Pubmed Central PMCID: PMC4081585. Epub 2014/07/06.

31. Galan F, Ribas J, Sanchez-Martinez PM, Calero T, Sanchez AB. Munoz A. Serum 25hydroxyvitamin $D$ in early autumn to ensure vitaniin $D$ sufficiency in mid-winter in professional football players. Clin Nutr. 2012 Feb;31(1):132-6. PubMed PMID: 21843910. Epub 2011/08/17.

32. Kopec A, Solarz K, Majda F, Slowinska-Lisowska M, Medras M. An evaluation of the levels of vitamin $\mathrm{d}$ and bone turnover markers after the sumpner and winter periods in polish professional soccer players. J Hum Kinet. 2013;38:135-40. PubMed PMHO924232955. Pubmed Central PMCID: PMC3827761. Epub 2013/11/16.

33. Solarz K, Kopec A, Pietraszerwska J, Majda Slowinska-Lisowska M, Medras M. An evaluation of the levels of 25-hydroxyvitamin D3and eone turnover markers in professional football players and in physically inactive men. Physio Res. 2014,63(2):237-43. PubMed PMID: 24397809. Epub 2014/01/09.

34. Hamilton B, Whiteley R, Farooq A, Chalabi H. Vitamin D concentration in 342 professional football players and assoeiation with Power limb isokinetic function. J Sci Med Sport. 2014 Jan;17(1):139-43. PubMed PMID: 23623203. Epub2013/04/30.

35. Maroon IC, Mathyssek CAM, Bost JW, Amos A, Winkelman R, Yates AP, et al. Vitamin D profile in National Fogtball League players. Am J Sports Med. 2015 May;43(5):1241-5. PubMed PMID: 25649084. Epub 2015/02/05.

36. Angelini FM, F.; Stesina, G.; Stefanini, L.; Bonuccelli, A.; Beschi, S.; Buonocore, D.; Rucci, S.; Tencone, F. Seasoriar pattern of vitamin D in male elite soccer players. Journal of the International Society of Sports Nutrition. 2011;8:35.

37. Hanwell HE, Vieth R, Cole DE, Scillitani A, Modoni S, Frusciante V, et al. Sun exposure questionnaire predicts circulating 25-hydroxyvitamin D concentrations in Caucasian hospital workers in southern Italy. J Steroid Biochem Mol Biol. 2010 Jul;121(1-2):334-7. PubMed PMID: 20298782. Epub 2010/03/20.

38. Obesity. A report of the Royal College of Physicians. J R Coll Physicians Lond. 1983 Jan;17(1):5-65. PubMed PMID: 6827490. Pubmed Central PMCID: PMC5370967. Epub $1983 / 01 / 01$.

39. Yanovski SZ. A practical approach to treatment of the obese patient. Arch Fam Med. 1993 Mar;2(3):309-16. PubMed PMID: 8252152. Epub 1993/03/01.

40. Expert Panel on Detection E, Treatment of High Blood Cholesterol in A. Executive Summary of The Third Report of The National Cholesterol Education Program (NCEP) Expert Panel on 
Detection, Evaluation, And Treatment of High Blood Cholesterol In Adults (Adult Treatment Panel III). JAMA. 2001 May 16;285(19):2486-97. PubMed PMID: 11368702. Epub 2001/05/23.

41. Holick MF, Binkley NC, Bischoff-Ferrari HA, Gordon CM, Hanley DA, Heaney RP, et al. Evaluation, treatment, and prevention of vitamin D deficiency: an Endocrine Society clinical practice guideline. J Clin Endocrinol Metab. 2011 Jul;96(7):1911-30. PubMed PMID: 21646368. Epub 2011/06/08.

42. Gudmundsdottir SL, Indridason OS, Franzson L, Sigurdsson G. Age-related decline in bone mass measured by dual-energy X-ray absorptiometry and quantitative ultrasound in a populationbased sample of both sexes: identification of useful ultrasound thresholds for osteoporosis screening. J Clin Densitom. 2005 Spring;8(1):80-6. PubMed PMID: 15722591. Epub 2005/02/22.

43. Arnason A, Sigurdsson SB, Gudmundsson A, Holme I, Engebretsen L, Bahr R. Risk factors for injuries in football. Am J Sports Med. 2004 Jan-Feb;32(1 Suppi):5S-16S. PubMed PMID: 14754854. Epub 2004/02/03.

44. Eirale C, Volpi P, Bisciotti GN. Injury epidemiology in Italian soccer: a @al for action. J Sports Med Phys Fitness. 2018 Oct;58(10):1554-5. PubMed PMID: 29199790. Epub 2017/12/05.

45. Peterson L, Junge A, Chomiak J, Graf-Baumann T, D vorak J. Incidence of football injuries and complaints in different age groups and skill-level groups. Am 5orts Med. 2000;28(5 Suppl):S51-7. PubMed PMID: 11032108. Epub 2000/10/14.

46. Giza E, Mithofer K, Farrell L, Zarins B, Gili T. Injuries in women's professional soccer. Br J Sports Med. 2005 Apr;39(4):212-6; discussion -6. PubMed RMH. 15793089. Pubmed Central PMCID: PMC1725176. Epub 2005/03/29.

47. Morton JP, Iqbal Z, Drust B, Burgess D, Close GL, Brikner PD Seasonal variation in vitamin D status in professional soccer players of the English Premier Legue. Appl Physiol Nutr Metab. 2012 Aug;37(4):798-802. PubMed PMID: 22554144 Epon 2013\%105/05.

48. Wicherts IS, van Schoor NM, Boeke AJ, risser M Deeg DJ, Smit J, et al. Vitamin D status predicts physical performance and its, decline in - older persons. J Clin Endocrinol Metab. 2007 Jun;92(6):2058-65. PubMed PMID: 17341569. Epub_2003/103/08.

49. Houston DK, Cesari M, Ferrucci D, Cherubini A, Maggio D, Bartali B, et al. Association between vitamin D status and physical ferformance: the InCHIANTI study. J Gerontol A Biol Sci Med Sci. 2007 Apr;62 (4):440-6. Pub11ed PMHD:17452740. Pubmed Central PMCID: PMC2645652. Epub 2007/04/25.

50. Visser M Deeg DJ, Lips (P., Longitudinal Aging Study A. Low vitamin D and high parathyroid hormone levels as determinants of loss of muscle strength and muscle mass (sarcopenia): the Longitudinal Aging Study Atmsterdam. J Clin Endocrinol Metab. 2003 Dec;88(12):5766-72. PubMed PMID: 14671166. Epub 2003/12/13.

51. Close GL, Leckey J, Patterson M, Bradley W, Owens DJ, Fraser WD, et al. The effects of vitamin $\mathrm{D}(3)$ supplementation on serum total $25[\mathrm{OH}] \mathrm{D}$ concentration and physical performance: a randomised dose-response study. Br J Sports Med. 2013 Jul;47(11):692-6. PubMed PMID: 23410885. Epub 2013/02/16.

52. Brahm H, Strom H, Piehl-Aulin K, Mallmin H, Ljunghall S. Bone metabolism in endurance trained athletes: a comparison to population-based controls based on DXA, SXA, quantitative ultrasound, and biochemical markers. Calcif Tissue Int. 1997 Dec;61(6):448-54. PubMed PMID: 9383270. Epub 1998/02/12.

53. Madsen OR, Sorensen OH, Egsmose C. Bone quality and bone mass as assessed by quantitative ultrasound and dual energy $\mathrm{x}$ ray absorptiometry in women with rheumatoid arthritis: relationship with quadriceps strength. Ann Rheum Dis. 2002 Apr;61(4):325-9. PubMed PMID: 11874835. Pubmed Central PMCID: PMC1754061. Epub 2002/03/05. 
1

54. Faulkner KG, McClung MR, Coleman LJ, Kingston-Sandahl E. Quantitative ultrasound of the heel: correlation with densitometric measurements at different skeletal sites. Osteoporos Int. 1994 Jan;4(1):42-7. PubMed PMID: 8148571. Epub 1994/01/01.

55. Licata A. Bone density vs bone quality: what's a clinician to do? Cleve Clin J Med. 2009 Jun;76(6):331-6. PubMed PMID: 19487553. Epub 2009/06/03.

56. Kanis JA, Johnell O, Oden A, Johansson H, McCloskey E. FRAX and the assessment of fracture probability in men and women from the UK. Osteoporos Int. 2008 Apr;19(4):385-97. PubMed PMID: 18292978. Pubmed Central PMCID: PMC2267485. Epub 2008/02/23. 
Table 1. Clinical, biochemical and densitometric parameters in 16 professional male football players at the beginning and the end of league.

\begin{tabular}{|c|c|c|c|c|}
\hline \multirow[t]{2}{*}{ Parameters } & \multicolumn{2}{|c|}{ Mean \pm SD } & \multirow[t]{2}{*}{ Normal range } & \multirow[t]{2}{*}{$p$} \\
\hline & Beginning & End & & \\
\hline $\mathrm{SBP}(\mathrm{mmHg})$ & $111.8 \pm 10.8$ & $11.8 \pm 10.8$ & & $\mathrm{~ns}$ \\
\hline DBP (mmHg) & $76.8 \pm 9.5$ & $75.0 \pm 9.2$ & & ns \\
\hline Hight (cm) & $176.2 \pm 7.6$ & - & & - \\
\hline Weight $(\mathrm{kg})$ & $69.0 \pm 8.2$ & $9.2 \pm 7.4$ & & ns \\
\hline BMI $\left(\mathrm{kg} / \mathrm{m}^{2}\right)$ & $22.1 \pm 1.3$ & & & ns \\
\hline $\mathrm{WC}(\mathrm{cm})$ & $81.9 \pm 4.4$ & $81.8 \pm 4.4$ & 7590 & ns \\
\hline Serum albumin $(g / L)$ & $4.5 \pm 0.5$ & 0.3 & & ns \\
\hline Serum creatinine $(\mathrm{mg} / \mathrm{dl})$ & & & $0.9-1.3$ & ns \\
\hline Creatinine clearance $(\mathrm{ml} / \mathrm{min})$ & & & C) & ns \\
\hline Serum 25-OHD (ng/ml) & & & (2) $30-100$ & 0.008 \\
\hline Serum ALP (U/L) & & & $71-140$ & ns \\
\hline Serum iPTH (pg/ml) & & $21.4+24.4$ & $11-31$ & ns \\
\hline Serum calcium $(\mathrm{mg} / \mathrm{dl})$ & $9.9 \pm 04$ & 6.9 \pm 0.5 & $9.2-10.5$ & ns \\
\hline Serum phosphorus (mg & & $4.0 \pm 0.4$ & $3.1-4.9$ & $\mathrm{~ns}$ \\
\hline Urinary calcium $(\mathrm{mg} / 24$ & $151.6 \pm 59.4$ & $168.5 \pm 92.1$ & $51-260$ & ns \\
\hline Urinary phosphorus (mg/24h) & $934.0 \pm 274.3$ & $691.0 \pm 364.5$ & $350-1575$ & $\mathrm{~ns}$ \\
\hline Calcaneal ultrasonometer $\mathrm{T}-8 \mathrm{~S}$ & $1.7 \pm 1.1$ & $1.6 \pm 1.0$ & $0.2-3.4$ & ns \\
\hline Calcaneal ultrasonometer Z-s & $1.7 \pm 1.1$ & $1.6 \pm 1.0$ & $0.2-3.4$ & ns \\
\hline BQI (right feet) & $138.5 \pm 17.7$ & $133.7 \pm 15.3$ & $0-150$ & ns \\
\hline
\end{tabular}

Abbreviation: 25-OHD: 25-hydroxyvitamin D; ALP: total alkaline phosphatase; BMI: body mass index; BQI: bone quality index; DBP: diastolic blood pressure; iPTH: parathyroid hormone; ns: $p$ not statistically significant; SBP: systolic blood pressure; T-s: T-score of the calcaneus; WC: waist circumference; Z-s: Z-score of the calcaneus; -: not applicable. 
Page 40 of 40

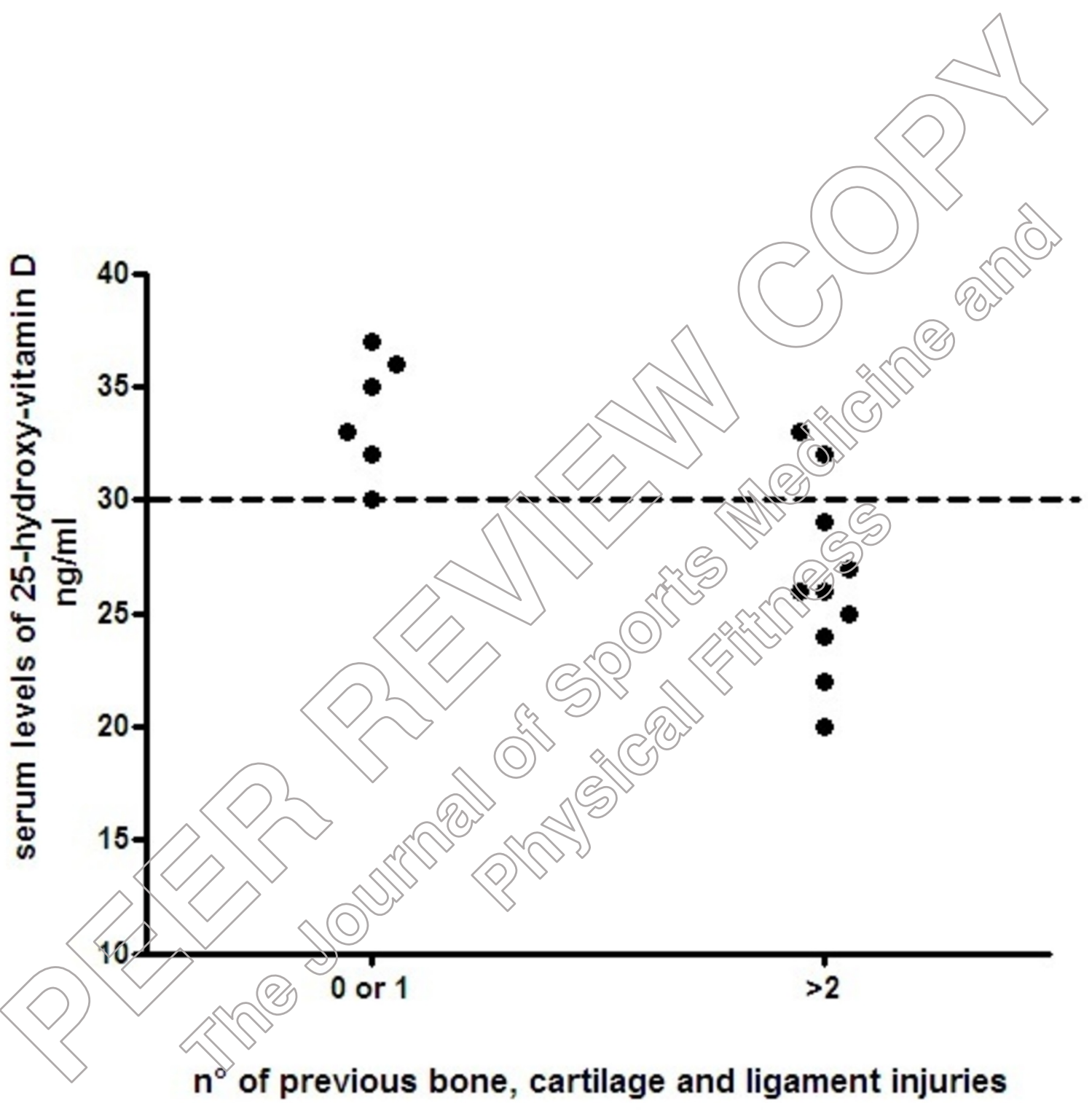

42

43

44

45

46

47

48

49

50

51

52

53

54

55 